\title{
Eindtermen zijn het begin
}

\section{Peter Eimers en Loek Vredevoogd}

SAMENVATTING Accountancy beweegt mee met de veranderingen in de samenleving en het onderwijs moet mee bewegen. Juist ten tijde van grote veranderingen in het beroep is het zinnig stil te staan bij de toekomst van de opleiding. Met de invoering van de Wet toezicht accountantsorganisaties (Wta) is ook de Commissie Eindtermen Accountantsopleiding (CEA) ingesteld als opvolger van het Examenbureau RA en het Examenbureau AA. De CEA heeft onlangs de 'Eindtermen theoretische Accountantsopleiding 2008' gepubliceerd als kader voor het curriculum van de accountantsopleidingen. Deze bijdrage beschrijft de nieuwe eindtermen accountantsopleiding in het licht van het verleden en met een blik op de toekomst

RELEVANTIE VOOR DE PRAKTIJK Eindtermen vormen de regelgeving voor accountantsopleidingen: ze zijn het spoorboekje voor de inrichting van het curriculum. De nieuwe eindtermen geven richting aan de opleidingsvereisten voor een nieuwe generatie accountants die optreden als wettelijk controleur.
1

\section{Inleiding}

Tot voor kort kenden we in Nederland twee sets afzonderlijke eindtermen, namelijk die van NIVRA en NOvAA. De RA-titel op academisch niveau, de AA-titel op HBO-plus niveau. Deze twee sets eindtermen waren niet aan elkaar gekoppeld. Twee opleidingsvereisten, terwijl de taak van wettelijke controleur is gebaseerd op één wettelijke bepaling, namelijk het mogen controleren van jaarrekeningen van grote en middelgrote ondernemingen.

Met de invoering van de $\mathrm{Wta}^{1}$ zijn ook de opleidingsregelingen in de WRA en WAA aangepast: de CEA stelt thans de eindtermen vast met inachtneming van de beroepsprofielen van NIVRA en NOvAA. Een belangrijke mijlpaal is hiermee bereikt doordat er nu voor externe accountants één set van eindtermen is met inachtneming van de specifieke opleidingsniveaus uit de beroepsprofielen.

In deze bijdrage worden deze eindtermen geplaatst in een perspectief van verleden, heden en toekomst. In paragraaf 2 staan wij stil bij de voorgeschiedenis van de huidige eindtermen zowel vanuit het gezichtspunt van het accountantsberoep als vanuit de opleidingen. In paragraaf 3 staan wij stil bij de basis voor de nieuwe eindtermen, waarbij ook de CEA en de beroepsprofielen aan de orde komen. In paragraaf 4 komen de eindtermen zelf aan de orde. Geen verleden en heden zonder toekomstperspectief: in paragraaf 5 verkennen wij de toekomst vanuit het besef dat de nieuwe eindtermen geen statisch gegeven zijn maar slechts het begin van nieuwe ontwikkelingen. Deze bijdrage wordt afgesloten met een samenvatting/conclusie.

\section{Achtergrond}

2.1 Accountancyopleiding in historisch perspectief

Wie vooruit wil kijken, kan soms beter ook even reflecteren op het verleden. We beginnen dan ook met een terugblik. Dat leert onder meer dat de opleiding 
en het eindexamen van de accountantsopleiding altijd onderwerp van discussie is geweest. Maatschappelijke ontwikkelingen, lokale regelgeving, betrokken organen, internationale richtlijnen, ze hebben allemaal in meer of mindere mate hun invloed op de inhoud van de opleiding gehad. Door de jaren heen is er ook steeds een levendig debat gevoerd over de verhouding tussen theorie en praktijk en wie de norm voor de opleiding stelt: de beroepsorganisatie of de opleiding. Dat Limperg een groot voorstander was van verwetenschappelijking van de studie is algemeen bekend (Limperg, 1929). Verschillende beroepsverenigingen worden opgericht met een gemeenschappelijk doel 'het bevorderen van een deskundige beroepsuitoefening. Uiteindelijk zijn er zo'n vijftien beroepsorganisaties. Een van de redenen overigens voor het oprichten van nieuwe beroepsorganisaties was dat de oprichters van een organisatie per definitie lid werden zonder examen te doen. De verschillende eisen die de beroepsorganisaties stellen aan de deskundigheid om als lid te kunnen worden toegelaten, onderscheidt hen. Zo staat het Nederlands Instituut van Accountants (NIVA) aanvankelijk sceptisch tegenover een universitaire opleiding. De Vereniging van Academisch Gevormde Accountants (VAGA), die later met het NIVA opgaat in het Koninklijk Nederlands Instituut van Registeraccountants (NIVRA), heeft uitsluitend leden met een academische achtergrond.

\subsection{Overheidsbemoeienis}

Tot de jaren zestig van de vorige eeuw blijft de overheidsbemoeienis beperkt. Overigens was het ondanks de geringe bemoeienis of interesse van de overheid altijd de vurige wens van het instituut om het accountantsberoep wettelijk te regelen. Uiteindelijk worden de versnippering en de van elkaar afwijkende toelatingseisen van de beroepsverenigingen reden voor de wetgever om regelend in te grijpen. In 1962 wordt de Wet op de Registeraccountants (WRA) ingevoerd. De invoering heeft voor de accountantsopleiding organisatorische consequenties. Zo moet er een onafhankelijk examenbureau ingesteld worden dat losstaat van het NIVRA. Bovendien wordt op grond van deze wet bij algemene maatregel van bestuur een examenbesluit afgekondigd waarin onder meer worden geregeld de inhoud en inrichting van het examen en toezicht daarop, waartoe de wetgever een curatorium heeft ingesteld. Het nieuwe autonome examenbureau functioneert ook als onderwijsbureau waarmee het Examenbesluit in de pas loopt met de nieuwe regeling ten aanzien van het NIVRA-onderwijs. Het NIVRA had in de WRA immers de verplichting gekregen een opleiding te verzorgen of doen verzorgen welke ging opleiden voor het wettelijke accountantsexamen.

\subsection{Democratisering in het onderwijs}

In de jaren zestig en zeventig van de vorige eeuw voltrekken zich in hoog tempo maatschappelijke ontwikkelingen die gevolgen hebben voor de opleiding. De Mammoetwet staat aan de basis van een grote reorganisatie van het onderwijs. De oprichting van de school voor hoger economisch en administratief onderwijs, de heao, is hier een voorbeeld van. De democratisering die in het onderwijs plaatsvindt, opent de discussie over de invloed en inspraak van de assistent-accountant. In 1971 wordt de Vereniging van Accountancy-Studenten (VAS) opgericht. De VAS ontwikkelt zich tot een belangrijke gesprekspartner van het NIVRA bij de herinrichting van het onderwijs. In 1979 wordt door middel van een verordening het Algemeen Bestuur Onderwijs NIVRA (ABON) opgericht, waarbij het NIVRA zijn onderwijstaken aan dit bestuur mandateert. Studenten krijgen zitting in het $\mathrm{ABON}$ en mogen deel uitmaken van de onderwijswerkgroepen die per vak het onderwijs invulling geven.

Midden jaren zeventig kregen de heao-opleidingen een differentiatie accountancy. Het NIVRA kreeg als onderwijsinstelling een belangrijke invloed op het curriculum van de scholen die deze accountancyvariant aanbieden, wat verband hield met de door het Examenbureau en de scholen te sluiten vrijstellingsovereenkomsten. Het nieuwe opleidingsaanbod was een enorm succes en daarmee werd de heao een belangrijk alternatief voor de basis van de opleiding tot registeraccountant.

\subsection{Tweefasestructuur}

In de jaren tachtig onderging de structuur van het wetenschappelijk onderwijs drastische veranderingen door de invoering van de tweefasestructuur. Hierdoor verdween - na jaren overleg - begin jaren negentig de universitaire accountancyopleiding uit het Academisch Statuut. De opleidingen werden in de nieuwe structuur aangemerkt als een postdoctorale opleidingsactiviteit, maar werden buiten het academische kader geplaatst. Door de wijziging konden studenten tot deze postdoctorale opleiding worden toegelaten die geen doctoraalopleiding hadden gevolgd. Overigens is dit laatste door een convenant tussen NIVRA en de universitaire opleiders begin $21^{\mathrm{e}}$ eeuw niet meer mogelijk: iedere RA-student moet een academische mastertitel behalen. De universitaire accountantsopleiding bleef wel voldoen aan de eisen die het Examenbureau stelt op grond van de erken- 
ningsregeling die in 1993 in de WRA is opgenomen en gebaseerd is op de gelijkwaardigheid met het wettelijke accountantsexamen.

Om NIVRA-studenten ook de mogelijkheid te bieden om aan een universiteit de doctorandustitel te halen, ging $\mathrm{ABON}$ in 1994 een samenwerking aan met Universiteit Nijenrode. Het NIVRA en Nijenrode sloten een raamcontract voor de ontwikkeling van een gemeenschappelijke doctoraalopleiding 'accountancy' waarin het wettelijke accountantsexamen geïncorporeerd is. De NIVRA-Nijenrode opleiding was tot aan de gewijzigde wetgeving van 2006 de benchmarkopleiding voor de opleiding tot registeraccountant.

Aan de zijde van accountants-administratieconsulenten begon de historie in 1948 met de oprichting van de Nederlandse Orde van Accountants. Met de invoering van de WRA in 1962 en daarmee de beschermde titel voor registeraccountants dreigden de accountants-administratieconsulenten buiten de boot van een wettelijke regeling te vallen. Uiteindelijk werd in 1974 de Nederlandse Orde van AccountantsAdministratieconsulenten (NOvAA) opgericht en werd de titel beschermd en werd uiteindelijk ook de opleiding voor accountants-administratieconsulenten neergezet.

\subsection{Europese wetgeving en stageverplichting}

Ook op Europees niveau laaide de discussie over wettelijke controle en de grote invloed van de beroepsorganisaties op de opleidingen regelmatig op. In 1984 werd door de Raad van Europese Gemeenschappen de Achtste Richtlijn vastgesteld en in 1999 de Bologna-verklaring die ten doel had te komen tot een gemeenschappelijk en open Europees hoger onderwijs met onderling vergelijkbare graden en diploma's. De WRA en Wet Accountants-Administratieconsulenten (WAA) die op de Achtste Richtlijn werden angepast, hadden consequenties voor de opleiding. Aan de bestaande eisen van het theoretische gedeelte van het accountantsexamen werd de eis van een praktijkopleiding toegevoegd. Er werd afgesproken dat de twee beroepsgroepen hun eigen opleidingseisen en de daarbij behorende titel kunnen behouden.

In 1993 brachten de ministers van Economische Zaken en Justitie in een wijzigingswet de WRA en de WAA in overeenstemming met Europese Richtlijnen. Deze harmonisatieslag heeft er onder meer toe geleid dat accountants-administratieconsulenten bij wet verplicht gestelde jaarrekeningcontroles mogen uitvoeren. Het vormde ook de basis voor de driejarige praktijkstage voor aankomende registeraccountants en accountants-administratieconsulenten.

\subsection{Internationale invloeden}

Met de uitbreiding van de Europese invloed ten aanzien van wetgeving, ontwikkelen het beroep en onderwijs zich ook steeds meer tot een internationaal georiënteerd vakgebied. Er wordt rekening gehouden met vraagstukken die de internationale dimensie van de bedrijfsvoering met zich meebrengt.

De Nederlandse universiteiten besluiten om hun programma's zo op te zetten dat het mogelijk wordt de opleiding niet alleen te volgen aan een andere universiteit, maar ook in het buitenland en soms zelfs in een andere studierichting dan de voorafgaande bacheloropleiding. In Nederland heeft de Bolognaverklaring onder andere geleid tot de invoering van de bachelor-masterstructuur in 2002. Een van de uitingen hiervan is de invoering van het European Credit Transfer System (ects) voor elk vak, waardoor de mobiliteit van studenten tussen onderwijsinstellingen en tussen landen wordt bevorderd.

Behalve de internationalisering hebben ook de enorme veranderingen in de maatschappij grote invloed op de opleiding. Denk bijvoorbeeld aan de veranderingen op het gebied van informatietechnologie. De accountant zal de belangrijkste aspecten daarvan moeten begrijpen en weten welke mogelijkheden deze nieuwe technologie biedt, maar ook de risico's die daarmee samenhangen voor de jaarrekening. Taak van de opleidingen dus om hierop in te spelen. Ook moeten de opleidingen snel inspelen op de veranderende regelgeving, zoals IFRS, toezicht, fraude- en onafhankelijkheidsregels, Sarbanes-Oxley, corporate governance en de aanpassingen in de International Standards on Auditing (ISA).

Ook de veranderingen in de praktijk van accountants in de afgelopen tien jaar zijn niet aan de inhoud van de opleidingen voorbijgegaan. Daar waar de praktijk van accountants zich in snel tempo verbreedde met aanvullende diensten, werden naast het traditionele postdoctorale curriculum specifieke opleidingen geïntroduceerd en uitgebreid, onder andere op het gebied van forensische accountancy, EDP-audit, operational audit en overheidsaccountancy. Een dergelijke verbreding is ook zichtbaar bij de opleiding tot AA-Belastingconsulent. Deze laatste opleidingen vormen geen onderdeel van de reguliere accountantsopleiding, maar zijn een gespecialiseerde vervolgopleiding.

\subsection{Wta}

De meest recente invloed op de accountantsopleiding stamt uit 2006 en is gekoppeld aan de Wet toezicht accountantsorganisaties (Wta). De Wta regelt het toezicht op accountantsorganisaties en individuele 
accountants die wettelijke controles uitvoeren. Met dit toezicht beoogt de wetgever het vertrouwen in de accountant te borgen, inclusief de verklaringen die de accountant voor het publiek afgeeft. Naast het toezicht op het functioneren van accountantsorganisaties is bij de invoering van deze wet ook het toezicht op de accountantsopleidingen in Nederland herzien. Met de aanpassingen in de WRA en WAA mocht het toezicht op de accountantsopleiding niet meer door de beide examenbureaus worden gehouden. Deze taak kwam op grond van artikel 66 e.v. van de WRA en artikel 56 e.v. uit de WAA bij de CEA te liggen, een zelfstandig bestuursorgaan dat is ingesteld door de minister van Financiën. In de CEA zijn accountantsadministratieconsulenten en registeraccountants vertegenwoordigd, onder leiding van een onafhankelijke voorzitter.

\section{Basis voor de nieuwe eindtermen}

\subsection{Taken van de CEA}

$\mathrm{Na}$ de historische schets van de accountantsopleidingen in de vorige paragraaf, gaan wij in deze paragraaf in op de basis voor de nieuwe eindtermen.

Op grond van de WRA (voor registeraccountant) respectievelijk WAA (voor accountant-administratieconsulent) heeft de CEA tot taak het vaststellen van de (theoretische en praktijk)eindtermen van de accountantsopleidingen in Nederland. Daarnaast wijst de CEA opleidingen aan die geheel of gedeeltelijk voldoen aan de theoretische eindtermen. Bovendien toetst de CEA de mate waarin aan de eindtermen van de praktijkopleiding wordt voldaan. Naast deze taken draagt de CEA ook zorg voor de afgifte van de verklaring van vakbekwaamheid die betrekking heeft op de toelating tot het accountants-

Kader 1 Voorwaarden voor een goede accountantsopleiding

De onderwijsinstelling moet het volgende kunnen aantonen:

- kwalificatie-eisen (geformuleerd als eindtermen);

- een curriculum (structuur en inhoud van de opleiding);

- onderwijsprogramma's, gebaseerd op onderwijsleerdoelen;

- regelingen aangaande toetsing, evaluatie en selectie;

- interne kwaliteitsbewaking (evaluatie van onderwijs en docenten);

- externe kwaliteitstoetsing (visitatie/accreditatie en beleidsgesprekken/ aanwijzingen);

- aandacht voor permanente curriculumbijstelling en -ontwikkeling;

- systematische deskundigheidsbevordering van docenten en examinatoren.

Bron: Eindtermen theoretische Accountantsopleiding 2008 beroep van buitenlandse accountants.

Voor het bereiken en in stand houden van een kwalitatief goede accountantsopleiding moeten naar het oordeel van de CEA enkele essentiële kwaliteitsvoorwaarden vervuld zijn (zie kader 1). Deze voorwaarden worden getoetst door middel van beleidsgesprekken en visitaties.

\subsection{Basis voor de eindtermen}

De eisen voor het theoretische deel van de opleiding tot wettelijk controleur, zoals beschreven in de EURichtlijn (2006/43) voor wettelijke controles van jaarrekeningen en geconsolideerde jaarrekeningen, zijn het uitgangspunt voor de eindtermen. Deze richtlijn beschrijft de minimumeisen waaraan een opleiding tot wettelijk controleur dient te voldoen, en de vakgebieden die in zo'n opleiding aan de orde moeten komen. Een voltooide accountantsopleiding (inclusief praktijkopleiding), die recht geeft op inschrijving in het AA- of het RA-register, moet (ook) voldoen aan de eisen van bovenbedoelde EU-Richtlijn.

In de Nederlandse accountantswet- en regelgeving wordt voor de opleiding aangesloten op c.q. verwezen naar (de vakgebieden van) de richtlijn. De richtlijn verdeelt de vakgebieden in twee categorieën. De eerste categorie betreft de vakgebieden waarvan de theoretische kennis met name in het examen getoetst dient te worden; de tweede categorie betreft de vakgebieden die eveneens getoetst dienen te worden, dat wil zeggen "voor zover deze voor de wettelijke controle van jaarrekeningen van belang zijn". De richtlijn laat relatief veel ruimte voor een eigen invulling door de lidstaten; in feite wordt - binnen kaders - slechts aangegeven welke (specifieke onderdelen van dan wel onderwerpen uit) vakgebieden aan de orde moeten komen en dat de meeste aandacht dient uit te gaan naar de kernvakgebieden.

In de richtlijn worden - vrij vertaald - als kernvakgebieden aangemerkt: boekhouden, externe verslaggeving en controleleer. In Nederland wordt boekhouden als een ondersteunend vakgebied gezien, terwijl hier het vakgebied van Bestuurlijke Informatieverzorging (BIV) als kernvakgebied wordt beschouwd. In de meeste andere EU-lidstaten is BIV geen afzonderlijk kernvakgebied en zijn de eindtermen die tot dit vakgebied behoren, aan de andere (kern)vakgebieden gerelateerd c.q. hierin opgenomen.

Naast de Achtste EU-Richtlijn heeft de CEA ook rekening gehouden met de door de International Federation of Accountants (IFAC) uitgegeven International Education Standards. Deze standaarden vormen een onderdeel van het kwaliteitsraamwerk 
van IFAC; de basis voor competente accountants ligt namelijk in de opleidingssfeer. Niet alleen de vaktechniek en praktijkervaring zijn belangrijk, maar ook professionele vaardigheden zoals interpersoonlijke en communicatieve vaardigheden en professionele waarden zoals ethiek en gedrag. Met deze laatste categorie wordt bijvoorbeeld in een Nederlandse context gedoeld op de toepassing van de Verordening Gedrags Code, deNadereVoorschriftenvoorOnafhankelijkheid en het optreden van de accountant in de Algemene Vergadering van Aandeelhouders. De door de CEA gemaakte koppeling tussen de Achtste EU-Richtlijn en de IFAC Education Standards is relevant in het kader van de EU-doelstelling om voor wettelijke controles in Europa te komen tot uniformering van bestaande landelijke controlestandaarden. De door de IFAC uitgegeven ISAs zijn hierbij de sleutel tot harmonisatie van controlestandaarden.

\subsection{Beroepsprofielen}

Op basis van artikel 66 van de WRA en artikel 56 van de WAA moet de CEA bij het vaststellen van de eindtermen de beroepsprofielen van beide beroepsorganisaties in acht nemen. Dit houdt in dat het NIVRA en NOvAA een specifieke invulling van de eindtermen kunnen verlangen voor hun doelgroep.

Concreet betekent dit dat de NOvAA in het beroepsprofiel specifieke aandacht vraagt voor de positie van de accountant-administratieconsulent in het mkb dat tot uiting komt in vakken als strategisch management in mkb en belastingrecht. Vanuit het NIVRA wordt benadrukt dat de registeraccountant-opleiding gebaseerd moet zijn op een academische mastertitel. De CEA heeft met deze beide beroepsprofielen rekening gehouden bij de vaststelling van de eindtermen.

De eindtermen beschrijven primair de eisen die gesteld worden aan de wettelijke controle van jaarrekeningen en geconsolideerde jaarrekeningen, inclusief de daaruit voortvloeiende natuurlijke adviesfunctie. Secundair zien de eindtermen op de bredere functie van de accountant-administratieconsulent en registeraccountant. De eindtermen beschrijven echter niet het volledige beroepsprofiel van de accountantadministratieconsulent en registeraccountant op hetzelfde eindniveau als voor de functie van wettelijk controleur van jaarrekeningen. De door de CEA vastgestelde eindtermen zijn ook dienstbaar aan de andere functies dan die van de wettelijke controle van jaarrekeningen door de accountant-administratieconsulent en registeraccountant. Het is aan de onderwijsinstellingen zelf om hier verder vorm en invulling aan te geven, zonder uiteraard de realisatie van de eindtermen voor de wettelijk controleur daarmee in gevaar te brengen. Dit biedt onderwijsinstellingen bij uitstek de mogelijkheid om de opleiding een eigen kleur en identiteit te geven en zich daarmee, indien gewenst, te onderscheiden van andere accountantsopleidingen.

\section{$\triangle$ De nieuwe eindtermen}

\subsection{Kenmerken}

In het onderwijs zijn eindtermen de basis voor de kwalificatie-eisen voor het diploma. Eindtermen geven antwoord op de vraag wat een persoon die de opleiding heeft afgerond, weet en kan uitvoeren. De CEA heeft bij de keuze voor eindtermen een aantal kenmerken gedefinieerd (Zie kader 2).

\footnotetext{
Kader $\mathbf{2}$ Kenmerken van de nieuwe eindtermen

De kenmerken van de nieuwe eindtermen zijn:

- De eindtermen zijn zo algemeen als mogelijk en zo specifiek als nodig geformuleerd.

- De eindtermen zijn beschreven op het eindniveau; de weg ernaartoe is aan de opleiders

- Voor registeraccountants geldt een academische mastertitel.

- Voor accountants-administratieconsulenten geldt een hbo-bachelortitel aangevuld met mkb-gerichte vakken.

- Aanvullend gelden er inhoudsvereisten van de accountancygerelateerde vakken (200 ECTS).

- Onderscheid naar kernvakgebieden, aan de kernvakgebieden gerelateerde vakgebieden en overige ondersteunende vakgebieden.
}

Bron: Eindtermen theoretische Accountantsopleiding 2008

Er is bewust voor gekozen om één set eindtermen voor zowel de opleiding tot accountant-administratieconsulent als registeraccountant te ontwerpen. De reden hiervoor is dat beide beroepsbeoefenaren dezelfde bevoegdheid hebben wettelijke controles van jaarrekeningen uit te voeren. In de beroepsprofielen van NIVRA en NOvAA wordt erkend dat de accountantadministratieconsulent en registeraccountant deels elk een eigen markt(segment) bedienen en een productportfolio aanbieden dat specifiek op die markt toegesneden is. Daarom wordt in de eindtermen ruimte gelaten verschillen in marktsegment en beroepsprofiel tot uitdrukking te brengen. Voorop staat echter dat iedere wettelijke controle van de jaarrekening waarop de accountantsverklaring wordt gebaseerd aan dezelfde voorwaarden uit de wet- en regelgeving dient te voldoen. Elke beroepsbeoefenaar die gerechtigd is om wettelijke controles uit te voeren, moet daarom voldoen aan de basiseisen van de eindtermen. 
De eindtermen zien op de beginnende beroepsbeoefenaar. Dit betekent dat van een afgestudeerde accountant-administratieconsulent en registeraccountant niet verwacht mag worden dat deze zelfstandig alle situaties en alle soorten van opdrachten kan vervullen. De accountant-administratieconsulent en registeraccountant hebben beiden een eigen verantwoordelijkheid die in de geldende beroepsregels is verankerd om voor elke opdracht of situatie afzonderlijk te beoordelen of en op welke wijze zij deze kunnen uitvoeren.

\subsection{Functies van de eindtermen}

De eindtermen voor de accountantsopleiding vervullen verschillende functies. Allereerst geven de eindtermen richting en sturing aan de inhoud van de accountantsopleidingen, waardoor de kwaliteit wordt geborgd. De eindtermen vormen tevens de kern van de domeinspecifieke aspecten van het toetsingskader voor de accreditatie van bachelor- en masteropleidingen door de Nederlands-Vlaamse Accreditatie Organisatie (NVAO) en voor het aanwijzen van opleidingen door de CEA. Ook bieden de eindtermen de mogelijkheid tot het maken van landelijk bruikbare onderwijsprogramma's en landelijke toetsen. In het bijzonder draagt de landelijke toetsing bij aan het borgen van de minimumkwaliteit van de opleiding die de CEA als eis heeft gesteld voor het verkrijgen van een aanwijzing.

Tot slot zijn de eindtermen van belang in het kader van de verklaring van vakbekwaamheid die de CEA afgeeft. Zo zijn de desbetreffende eindtermen ook van toepassing op de examens Nederlands recht en gedrags- en beroepsregels die op grond van artikel 57 WAA en artikel 78 WRA verplicht zijn voor personen van binnen de EU/EER een verklaring van vakbekwaamheid willen krijgen. Daarnaast zijn de eindtermen relevant voor de beoordeling van de vergelijkbaarheid van diploma's van personen van buiten de EU/EER die een verklaring van vakbekwaamheid willen krijgen.

\subsection{Praktijkstage}

Zoals hiervoor al aangegeven is, omvat de accountantsopleiding zowel een theoretisch deel als een praktijkdeel. De theoretische opleiding wordt gevolgd bij een of meer onderwijsinstellingen. De praktijkopleiding wordt gevolgd via een door de beroepsorganisaties erkend stagebureau. De verantwoordelijkheid voor de inrichting van de praktijkopleiding en het examen van de praktijkopleiding ligt bij de beroepsorganisaties.

De praktijkopleiding heeft primair als doel om vast te stellen of een persoon de theoretische kennis in de praktijk kan toepassen. In het algemeen volgt een student een gedeelte van de praktijkopleiding gelijktijdig met het laatste deel van de theoretische opleiding. Daardoor bestaat er automatisch een wisselwerking tussen theoretische opleiding en praktijkopleiding, iets wat als zeer nuttig wordt ervaren. Om de opleiding effectiever te maken zonder de studieduur te vergroten, moet de synergie tussen theoretische opleiding en praktijkopleiding zo groot mogelijk zijn. De opzet van de eindtermen voor de theoretische opleiding en de praktijkopleiding zal daarom waar mogelijk grotendeels gelijk zijn. Op een later moment zal de CEA de eindtermen voor de praktijkopleiding publiceren.

\subsection{De inrichting van de eindtermen}

Voor de in de EU-Richtlijn genoemde vakgebieden, waarvan de theoretische kennis in een (accountantadministratieconsulent- of registeraccountant-)opleiding getoetst dient te worden, is een basisstudiebelasting vastgesteld. Deze basisstudiebelasting omvat - gerelateerd aan desbetreffende vakgebieden - het aantal studie-uren dat een voltijdstudent ten minste nodig heeft om het minimaal vereiste theoretische niveau voor de (beginnend) wettelijk controleur te verwerven.

Mede op grond van een analyse van de bestaande studietrajecten - die in grote lijnen een goede basis vormden om te voldoen aan de EU-Richtlijn - en de beroepsprofielen van de NOvAA en het NIVRA is er een vereiste vastgesteld voor een hbo-bachelortitel voor de AA-opleiding en een academische mastertitel voor de RA-opleiding. Daarbij geldt een minimale basisstudiebelasting van 200 ects aan vakken die voor accountants relevant zijn. Dit betekent dat opleiders de mogelijkheid hebben om de specifiek in te vullen vakken in te vlechten in hun opleidingsprogramma, maar dat het niet waarschijnlijk is dat zij de gehele 200 ects hierin onder kunnen brengen als gevolg van de accreditatievereisten van de NVAO voor opleidingen op het niveau van hoger beroepsonderwijs (hbo) en wetenschappelijk onderwijs (wo). Voor de huidige AA-opleiding geldt thans al dat een deel van de totale basisstudiebelasting (na de hbo-bachelor in accountancy van 240 ects) in een post-hbo-opleiding is opgenomen. In de RA-opleiding omvat een deel van de basisstudiebelasting nu ook een deel van de postacademische opleiding. In beide studietrajecten komt het totale aantal ects daarmee (ruim) boven de 240. Naar verwachting zal door de nieuwe eindtermen het studietraject voor de AA-opleiding voornamelijk bij de hoofdvakken verzwaard worden en zullen 
Kader 3 Samenvatting minimaal aantal studiepunten per vakgebied van een accountantsopleiding

\begin{tabular}{|l|c|}
\hline In het curriculum op te nemen vakgebieden & $\begin{array}{l}\text { Minimaal totaal } \\
\text { per categorie }\end{array}$ \\
\hline Kernvakgebieden & 90 \\
\hline Auditing \& assurance, externe verslaggeving, bestuurlijke informatieverzorging & (ieder minimaal 30) \\
\hline Aan de kernvakgebieden gerelateerde bedrijfseconomische/ accountancy vakgebieden & 65 \\
\hline $\begin{array}{l}\text { Boekhouden, management accounting, financieel management/ financiering, management en organisatie, corporate } \\
\text { governance }\end{array}$ & \\
\hline Overige ondersteunende vakgebieden & 45 \\
\hline Recht, belastingrecht, algemene economie, wiskunde en statistiek & \\
\hline Totaal & $\mathbf{2 0 0}$ \\
\hline
\end{tabular}

(zie voor meer details de Eindtermen theoretische Accountantsopleiding 2008)

opleidingen wellicht een eerdere specialisatie voor accountancy in het voortraject mogelijk maken; voor de RA-opleiding zijn er nuanceverschillen te verwachten die afhankelijk zijn van de inrichting van de huidige studiebelasting per vak per opleiding.

\subsection{Ects-effecten}

Voor het bepalen van de studielast is aangesloten op het in Europa in het kader van de bachelor-masterstructuur geldende ects-systeem waarbij één studiepunt staat voor 28 studie-uren. Het ects-systeem maakt weliswaar geen onderscheid naar hbo en wo, maar in het Nederlandse stelsel voor hoger onderwijs kan een 'hbo-ects' niet gelijk worden gesteld aan een 'wo-ects'. Daarom is het te bereiken eindniveau van een vierjarige hbo-bachelor (240 ects) niet hetzelfde als dat van een driejarige wo-bachelor (180 ects) of dat van een wo-bachelor + éénjarige master (240 ects). Met andere woorden: de accountantsopleidingen in het wo zullen de beschreven eindtermen in minder ects kunnen realiseren dan de opleidingen in het hbo, maar tegelijkertijd vanwege de noodzakelijk geachte academische vorming aan meer en in zekere zin ook andere eisen moeten voldoen. Dit geldt voor zowel het totaal aantal ects als het aantal ects per vak. Het vorenstaande komt in het wo onder meer tot uitdrukking in:

- de benaderingswijze (met name inzichtgericht) van het onderwijsleerproces;

- het gebruik van overwegend wetenschappelijke literatuur;

- de complexiteit en de theoretische verdieping van de leerstof;

- het uitvoeren van wetenschappelijk onderzoek, respectievelijk het gebruik van de uitkomsten van wetenschappelijk onderzoek in het onderwijsleerproces.
Bovenstaande neemt niet weg dat zowel binnen het wo als hbo dezelfde eindtermen moeten worden gerealiseerd.

Naast de verplichting voor het schrijven van een thesis of scriptie in het wetenschappelijk onderwijs respectievelijk stage en afstudeeropdracht in het hbo, biedt het curriculum, uitgaande van de bestaande structuren, een zekere 'vrije ruimte'. Deze ruimte is onder meer bestemd voor:

- verbreding en verdieping van de wetenschappelijke component in met name de universitaire bachelor- en masteropleidingen;

- verdieping op het terrein van de kernvakken;

- verdieping vanuit het geldende beroepsprofiel;

- eigen profilering van de onderwijsinstelling.

Op grond van de hiervoor geschetste kaders, uitgangspunten en overwegingen is een toedeling van ects per vakgebied gemaakt (zie kader 3). Hierbij is uitgegaan van een minimaal aantal ects per categorie, met als doel het vereiste basisniveau voor het desbetreffende vakgebied te markeren. De kernvakgebieden dienen in ieder geval substantieel in de initiële opleidingen aan bod te komen. Het te bereiken eindniveau in deze vakken overstijgt daarbij het niveau van een bacheloropleiding. Voor elk vakgebied en per onderwerp is aangegeven welk niveau de student moet behalen: basisniveau, middenniveau of hoogste niveau. In het bijzonder voor de kernvakgebieden zal op veel onderdelen het hoogste niveau moeten worden gehaald.

De per categorie en vakgebied toegekende ects geven als geheel een representatief beeld van de relatieve zwaarte en de betekenis van de kernvakgebieden in een accountantsopleiding. Daarmee zijn ze een richt- 
snoer voor de mate van aandacht die voor het realiseren van de eindtermen ten minste moet worden gegeven aan het desbetreffende vakgebied.

\section{Toekomst}

Zijn we er met de nieuwe eindtermen? Nee, de eindtermen zijn slechts het begin van toekomstige ontwikkelingen. Zoals eerder beschreven leert de geschiedenis ons dat ook in de toekomst de eindtermen moeten worden geactualiseerd op basis van ontwikkelingen in het vak en de wetgeving. In die zin kan de opleiding dan ook niet los worden gezien van haar historie. De invoering van de Wta is zo'n scherpe scheidslijn in de geschiedenis. Het was voor de CEA essentieel om draagvlak te creëren voor de veranderingen. Wat voor de ene belanghebbende niet ver genoeg gaat - zie het pleidooi van Buyink (2007) over dit onderwerp, is een stap te ver voor andere belanghebbenden. Nieuwe richtingen zijn uitgezet en noodzakelijke aanpassingen zijn doorgevoerd, maar daar is een grens aan: de CEA kan niet te ver op de muziek vooruitlopen waardoor een deel van de belanghebbenden afhaakt. Ten opzichte van de oude eindtermen - zowel voor accountant-administratieconsulent als registeraccountant - zijn de nieuwe eindtermen minder gedetailleerd: ze kennen geen voorgeschreven literatuur en de opleider heeft alle vrijheid om het programma in te richten zolang de eindtermen maar worden behaald. Dat vraagt een expliciete verantwoordelijkheid van de opleider. Zo kan een opleider kiezen voor een strak georganiseerd programma 'zonder franje' door al in de bachelor- of masterfase veel specifieke accountantsvakken te behandelen en een andere opleider kan juist kiezen voor een brede (basis-)opleiding die verder kijkt dan alleen accountancyvakken. Beide keuzes hebben gevolgen voor de duur en positionering van de opleiding. Zo zouden hbo-opleidingen kunnen kiezen voor het in ere herstellen van een hbo-Accountancy (AC) opleiding waarbij vanaf het eerste jaar een volledig ACprogramma wordt gedraaid.

Een historische stap is met de nieuwe eindtermen gezet door met één set van eindtermen te komen voor de wettelijk controleur, of die nu accountant-administratieconsulent of registeraccountant is. Eén set van eindtermen, maar wel met inachtneming van de beroepsprofielen van de beide beroepsorganisaties. Daarmee zijn de eindtermen een compromis tussen de vrijheid van opleiders om een opleiding een eigen gezicht te geven ten opzichte van de gewenste en vereiste gemeenschappelijke basis in alle accountantsopleidingen, of ze nu op hbo- of wo-niveau zijn. Het is daarom van belang de ontwikkelingen in het beroepenveld van de accountant te volgen, zowel in Nederland als internationaal. In Nederland zal naar onze verwachting de vergunningverlening door de Autoriteit Financiële Markten (AFM) voor het uitvoeren van wettelijke controles leiden tot een grote uitdaging om accountants op te leiden die vanwege hun praktijkstage niet meer terechtkunnen bij kantoren die geen vergunning hebben gekregen. Groeien de openbaar accountants van het NIVRA en de NOvAA naar elkaar toe? Wordt het één beroepsorganisatie waarin iedere doelgroep een aparte 'kamer' heeft en alle openbaar accountants samen één kamer vormen? Het woord is aan de beroepsorganisaties en de kantoren. Dit zal uiteindelijk mogelijk directe of indirecte gevolgen hebben voor toekomstige aanpassingen in de eindtermen en opleidingen. Daarnaast speelt de internationale dimensie een belangrijke rol in de toekomstige ontwikkelingen van de eindtermen. Met de harmonisatie van Europese (toezicht op) regelgeving op het gebied van financiële verslaggeving, accountantsorganisaties, en in de nabije toekomst ook controlestandaarden, ontstaat er mogelijk een Europese markt voor accountants. Een van de consequenties kan zijn dat er in de toekomst een opleiding ontstaat voor een Europese accountant. Uitwisselbaarheid van opleidingsdiploma's en certificaten is hier instrumenteel aan, maar afwijkende opleidingsvereisten per land werken in dit kader belemmerend. De NIVRA-commissie Toekomst Accountancy Opleidingen (TAO) heeft hiervoor de eerste aanzet gegeven, waaronder de introductie van een basisaccountant. Het is echter nog te prematuur voor de Eindtermen theoretische Accountantsopleiding 2008 omdat het TAO-rapport nog in NIVRA verband wordt uitgewerkt.

Ten slotte nog de instroom in het beroep. De laatste jaren zijn steeds meer geluiden te horen dat de toegang tot het accountantsberoep niet voorbehouden moet zijn aan economisch geschoolde personen. Dit heeft enerzijds een demografische achtergrond, maar ook het toenemende besef dat een diversiteit aan leden van een controleteam leidt tot een betere kwaliteit van de controle. Met elkaar weet je namelijk meer. De beperkte instroom van mensen met een afwijkende vooropleiding was namelijk het effect van de strakke vereisten uit de voorgaande eindtermen voor registeraccountant.

De nieuwe eindtermen voorzien hier gedeeltelijk in: om registeraccountant te worden heb je een academische mastertitel nodig, maar dat kan ook in een ander vakgebied. Wel zal deze toekomstige accountant de accountancyspecifieke bagage in z'n rugzak moeten 
verzamelen om registeraccountant te worden. Deze persoon ontkomt er dus niet aan om wat langer dan gemiddeld te studeren. Universiteiten kunnen met maatwerkprogramma's de instroom vanuit andere vakgebieden stimuleren en daarmee de instroom in het accountantsberoep bevorderen.

\section{Conclusie}

Met de nieuwe eindtermen is er bewerkstelligd dat er één set van eindtermen is ontstaan voor alle wettelijke controleurs, of ze nu registeraccountant of accountant-administratieconsulent zijn. Eén set eindtermen met oog voor de verschillende beroepsprofielen. De opleidingen staan nu voor de uitdaging om de nieuwe eindtermen uit te werken in het opleidingsprogramma. $\mathrm{Zij}$ hebben binnen de geschetste kaders de ruimte om hun eigen profiel neer te zetten voor het opleiden van een nieuwe generatie accountants. Afgezien van de benodigde vaktechnische kennis staat niet het leren van feiten centraal in de moderne accountancyopleiding, maar het weten hoe professioneel te handelen in eenvoudige en complexe situaties. Kortom: leren navigeren met de nieuwe eindtermen!

\section{Literatuur}

Buijink, W. (2007), De opleiding, column, Maandblad voor Accountancy en Bedrijfseconomie, jg. 81, no. 5, mei, pp. 172, 173.

Commissie Eindtermen Accountantsopleiding (CEA) (2007), Eindtermen theoretische Accountantsopleiding 2008; zie: www. commissieeindtermen.nl.

Commissie van de Europese Gemeenschappen (2006), Richtlijn 2006/43/ EG van het Europees Parlement en de Raad van 17 mei 2006 betreffende de wettelijke controles van jaarrekeningen en geconsolideerde jaarrekeningen, tot wijziging van de Richtlijnen 78/660/EEG en 83/349/ EEG van de Raad en houdende intrekking van Richtlijn 84/253/EEG van de Raad, zie: http://europa.eu/scadplus/leg/nl/lvb/I26001.htm.

International Federation of Accountants (IFAC), International Education Standards $1 \mathrm{t} / \mathrm{m}$ 8; zie www.ifac.org/Education.

Koninklijk NIVRA (2007), De opleidingen tot registeraccountant, Rapport van de Commissie Toekomst Accountancy Opleidingen (TAO); zie: www.nivra.nl.

Limperg jr, Th. (1929), De betekenis der bedrijfshuishoudkunde voor de accountant, Maandblad voor Accountancy en Bedrijfshuishoudkunde, oktober, opgenomen in de bundel "1924 MAB 1960 inhoudende een aantal bijdragen gedurende deze jaren verschenen in het Maanblad voor Accountancy en Bedrijfshuishoudkunde", deel I, Bedrijfshuishoudkunde, pp. 1-8.

Koninklijk NIVRA en NOvAA (2007), Handleiding Regelgeving Accountancy (HRA): deel 1 Regelgeving voor de accountant; deel 2 Toelichting regelgeving; en deel 3 Voorbeeldteksten, 2007; zie: www.nivra.nl/ HRA/index.htm.
Wet toezicht accountantsorganisaties (Wta); zie: http://wetten.overheid. nl; www.nivra.nl/HRA/index.htm.

Wet op de Accountants-Administratieconsulenten (WAA); zie: http:// wetten.overheid.nl; www.nivra.nl/HRA/index.htm.

Wet op de Registeraccountants (WRA); zie: http://wetten.overheid.nl; www.nivra.nl/HRA/index.htm.

\section{Noten}

1 Alle wetten en verordeningen betreffende de regelgeving voor accountants zijn opgenomen in: Koninklijk NIVRA en NOvAA (2007), Handleiding Regelgeving Accountancy (HRA). 